\title{
Treatment modalities of palmoplantar lichen planus: a brief review
}

\author{
Amir Feily ${ }^{1}$, Reza Yaghoobi², Mohammad Ali Nilforoushzadeh ${ }^{1}$ \\ ${ }^{1}$ Skin and Stem Cell Research Center, Tehran University of Medical Sciences, Tehran, Iran \\ 2Jundishapur University of Medical Science, Ahvaz, Iran
}

Adv Dermatol Allergol 2016; XXXIII (6): 411-415

DOI: 10.5114/ada.2016.63879

\begin{abstract}
Palmoplantar lichen planus is a localized and uncommon variant of lichen planus which is mostly resistant to treatment. Our purpose was to discuss all treatment modalities proposed and tested for palmoplantar lichen planus in the literature. A systematic review of the literature was conducted to evaluate evidence regarding all treatment modalities proposed and tested for palmoplantar lichen planus in the literature. Two major databases (PubMed, Google scholar) were searched. The review included all case reports, letters and original articles reporting any treatment for palmoplantar lichen planus but not treatment used in the other type of lichen planus, generalized lichen planus or other type of palmoplantar dermatoses. We have gone over more than 50 articles. There are many drugs that have been used in the treatment of lichen planus and generalized lichen planus but the palmoplantar type is a rare variety of lichen planus. That is why we could not find any clinical trial on the subject and just case reports have been described in this manuscript. In spite of plentiful investigations carried out on lichen planus, there is no treatment modality that has proved to be utterly satisfactory in treatment of palmoplantar lichen planus.
\end{abstract}

Key words: treatment, palmoplantar lichen planus, review.

\section{Introduction}

Lichen planus (LP) is a common idiopathic inflammatory papulosquamous disorder that affects the flexor aspect of the wrists, legs, oral and genital mucosa. Nail and hair may be involved [1, 2]. Lichen planus can occur in many different shapes and locations such as annular, linear, hypertrophic, atrophic, bullous, ulcerative and pigmented ones [3-5]. Palmoplantar LP is a localized and uncommon variant of LP which is mostly resistant to treatment [6]. Interestingly, LP of palms and soles does not resemble classic LP and does not demonstrate Wickham's striae and its typical polygonal lesion [7]. Approximately in one-quarter of palmoplantar LP cases, typical lesions can be seen on the other skin and mucosal surfaces [6].

Many clinical variants of palmoplantar LP have been described in the literature such as erythematous scaly form which is the most common [7], pitted plaques [8], ulcerative lesions [8, 9], vesicle-like papules [10], umbilicated papules [7, 11], punctate keratoderma, perforating palmar LP $[7,11,12]$ and petechiae-like lesions [13]. Multiple variants can occur simultaneously within one individual [14].
Palmoplantar LP can pose a diagnostic problem to the clinician as it resembles many dermatoses, such as psoriasis, punctate porokeratosis, lichen nitidus, punctate palmoplantar keratoderma, reactive perforating collagenosis, syphilis, arsenical keratoses, porokeratotic eccrine ostial and dermal duct nevus, perforating granuloma anulare and Bazex's syndrome [2, 15-18]. In spite of plentiful investigations carried out on LP, there is no treatment modality that has proved to be utterly satisfactory in treatment of palmoplantar LP [8]. There are many drugs such as sulfasalazine, metronidazole, griseofulvin, thalidomide and therapeutic modalities such as UVA1 radiation and extracorporeal phototherapy that have been used in the treatment of LP and generalized LP [17] but just a few case reports and drugs used in the treatment of palmoplantar LP.

\section{Methods}

An extensive literature search from two databases, PubMed and Google scholar, was performed. In this review article we have gone over about 24 articles and we

Address for correspondence: Amir Feily, Skin and Stem Cell Research Center, Tehran University of Medical Sciences, No. 4, Maryam Alley, Southern Kermaniyeh St, Tehran, Iran, e-mail: dr.feily@yahoo.com Received: 28.07.2014, accepted: 2.02.2016. 
have aimed to discuss all treatment modalities proposed and tested for palmoplantar LP in the literature.

The main search terms used were 'palmoplantar LP, acitretin, enoxaparin, cyclosporine, systemic corticosteroid, topical corticosteroid, retinoic acid, topical cyclosporine, topical tacrolimus, surgery, steroid cream, UVA1, metronidazole, sulfasalazine, hydroxychloroquine, mycophenolate mofetil, griseofulvin and thalidomide (Table 1).

\section{Results}

\section{Acitretin}

In a Chinese case report, a 46-year-old man presented with a 1-month history of asymptomatic LP on his hands, wrists, and feet and 3-day history of erosions on his glans. He was treated with acitretin at an initial dose of $0.5 \mathrm{mg} / \mathrm{kg} /$ day $(30 \mathrm{mg} /$ day), which resulted in a significant improvement after 1 month of treatment. The dose of acitretin was tapered gradually for 2 months. No recurrence was observed during the follow-up period of 4 months [17]. Lospinoso et al. demonstrated a significant clinical response to systemic acitretin therapy in a patient with coexistence of palmoplantar LP and lupus erythematosus overlap syndrome with painful and atrophic palmoplantar involvement as a characteristic feature of this condition [19]. In another case report, De Jong et al. reported coexistence of palmoplantar LP and lupus erythematosus that well responded to acitretin with prolonged remission [8]. Several potential mechanisms such as immunomodulation, anti-inflammation, antiproliferative effects and regulating epidermal proliferation and differentiation have been proposed to explain why retinoids have therapeutic effects in treating LP [20].

\section{Enoxaparin}

There is one case report of successful treatment of palmoplantar hyperkeratotic LP with enoxaparin in 2 patients. Enoxaparin was administered at a dose of $3 \mathrm{mg}$ subcutaneously into the abdominal wall once a week.

Table 1. Main suggested treatment for palmoplantar lichen plantus

\begin{tabular}{|c|c|c|c|c|}
\hline Drug & Case & Dosage & Length of treatment time & Reference \\
\hline Acitretin & 46-year-old man & 0.5 mg/kg/day (30 mg/day) & One month & {$[17]$} \\
\hline Enoxaparin & $\begin{array}{l}\text { 24-year-old male } \\
\text { and } 45 \text {-year-old } \\
\text { male }\end{array}$ & $\begin{array}{l}3 \text { mg subcutaneously into the abdominal } \\
\text { wall once a week for } 3 \text { months }\end{array}$ & Improvement after 12 sessions & {$[3]$} \\
\hline Topical corticosteroids & Unknown & Topically applied & $\begin{array}{l}\text { Improvement after 2-9 months } \\
\text { but recurrence is frequently seen } \\
\text { after discontinuation of the drug }\end{array}$ & {$[21]$} \\
\hline $\begin{array}{l}\text { Combination of topical } \\
\text { corticosteroids and oral } \\
\text { acitretin }\end{array}$ & $\begin{array}{l}\text { 60-year-old } \\
\text { woman }\end{array}$ & $\begin{array}{l}\text { Topically applied corticosteroids + oral } \\
\text { acitretin }\end{array}$ & $\begin{array}{l}\text { Improvement after 2-month } \\
\text { follow-up }\end{array}$ & {$[22]$} \\
\hline Cyclosporine & $\begin{array}{l}\text { 63-year-old } \\
\text { woman }\end{array}$ & 3.5 mg/kg/day & $\begin{array}{c}\text { Improvement after } 4 \text { weeks of } \\
\text { treatment and then cyclosporine } \\
\text { tapered off gradually over the next } \\
4 \text { weeks, giving a total treatment } \\
\text { duration of } 8 \text { weeks }\end{array}$ & {$[4]$} \\
\hline Systemic corticosteroid & $\begin{array}{l}\text { 25-year-old } \\
\text { woman }\end{array}$ & 40 mg/day prednisolone & 6 weeks & {$[8]$} \\
\hline Retinoic acid (topical) & 68 patients & Topically applied & Few weeks & {$[7]$} \\
\hline Topical cyclosporine & $\begin{array}{l}\text { 81-year-old } \\
\text { female }\end{array}$ & $\begin{array}{l}500 \mathrm{mg} \text { of cyclosporine per day (50 mg } \\
\text { cyclosporine/ml) in topical oily dressings }\end{array}$ & Twice a week for 10 months & {$[24]$} \\
\hline Topical tacrolimus $0.1 \%$ & $\begin{array}{l}\text { 75-year-old } \\
\text { woman }\end{array}$ & Topically applied twice daily & 6 months & {$[25]$} \\
\hline Topical tacrolimus $0.1 \%$ & $\begin{array}{l}\text { 65-year-old } \\
\text { female }\end{array}$ & Topically applied twice daily & 4 weeks & {$[26]$} \\
\hline $\begin{array}{l}\text { Combination of a low } \\
\text { dose of cyclosporine } \\
\text { and steroid cream }\end{array}$ & $\begin{array}{l}\text { 68-year-old } \\
\text { woman }\end{array}$ & $\begin{array}{c}\text { Cyclosporine A } 2.5 \mathrm{mg} / \mathrm{kg} / \text { day and steroid } \\
\text { cream twice daily }\end{array}$ & 4 months follow up & {$[21]$} \\
\hline $\begin{array}{l}\text { Combination of surgery } \\
\text { and cyclosporine A }\end{array}$ & 68-year-old man & $\begin{array}{c}\text { Start of cyclosporine A } 10 \text { days before } \\
\text { Thiersch split-skin graft until } 10 \text { months } \\
\text { later }\end{array}$ & 10 months cyclosporine $\mathrm{A}$ & {$[27]$} \\
\hline Surgery & 2 reports & Excision and split skin graft & 14-year follow-up & {$[28]$} \\
\hline
\end{tabular}


Platelet count assays and coagulation parameters of the patients were within normal limits. A significant improvement was seen at the end of 12 sessions but oral mucosa lesions remained stable. No complication was seen in the patient [6]. Enoxaparin's mechanism of action is based on the inhibition of the heparanase enzyme released by active $T$ lymphocytes. Since the heparanase enzyme is inhibited by low-dose, low-molecular-weight heparin, T lymphocytes cannot reach their target tissue [21, 22]. It also inhibits the cytokines' role in inflammation, and especially the expression of tumor necrosis factor $\alpha$ [21].

\section{Cyclosporine}

Karakatsanis et al. demonstrated a case of a 63-yearold woman who presented with pruritic eruptions on her palms, forearms, soles and the lateral aspects of the feet and who responded very rapidly to cyclosporine [7].

\section{Systemic corticosteroid}

A Turkish case report presented a 25-year-old woman with a palmoplantar LP resistant to topical corticosteroids who responded well to systemic corticosteroid therapy [10].

\section{Combination of a low dose of cyclosporine and steroid cream}

There is a case of good response of a 68-year-old retired woman with palmoplantar LP who did not respond to steroid ointments to low doses of cyclosporine A of $2.5 \mathrm{mg} / \mathrm{kg} /$ day, in association with steroid cream twice daily. There was no recurrence for 4-month follow-up [23].

\section{Topical corticosteroids}

Topical-systemic corticosteroids and other treatment regimens provide healing within 2-9 months in most cases of palmoplantar LP, but recurrence is frequently seen after discontinuation of the drug [24].

\section{Combination of topical corticosteroids and oral acitretin}

In another case report, a 60-year-old woman presented with a very unusual palmoplantar eruption characterized by violaceous pustule-like papules treated with a combination of topical corticosteroids and oral acitretin. The eruption responded dramatically and resolved within 2-month follow-up [25].

\section{Retinoic acid (topical)}

In a study on 68 patients suffering from palmar/plantar hyperkeratoses of different etiology, small doses of vitamin A acid (retinoic acid) applied topically, produced a striking improvement in hypertrophic LP of palms or soles; the regression was complete and in most cases permanent [9].

\section{Topical cyclosporine}

Topical cyclosporine, which is not absorbed by the normal stratum corneum, has been used in mucosal forms of erosive LP, without undesirable secondary effects. There was no detectable cyclosporine level in blood during treatment, which probably depended both on the concentration of the solution used and the surface of application [26]. Paçi and Silva reported a case of an 81-year-old female with just ulcerative LP on the sole of her right foot, without any other lesions. Treatment with topical cyclosporine was started on the affected skin with $500 \mathrm{mg}$ of cyclosporine per day (50 mg cyclosporine/ml) in topical oily dressings applied on the plantar surface. The dressings were changed daily. The treatment was continued twice a week for 10 months with a considerable improvement. During the treatment cyclosporine was never detected in blood tests and the authors did not notice any undesirable secondary effects [26].

\section{Topical tacrolimus $0.1 \%$}

It has been reported a case of a 75-year-old woman with ulcerative LP of the sole, who responded well to tacrolimus $0.1 \%$ cream prescribed for application once daily. After 2 months tacrolimus application was increased to twice daily and the ulcer had almost completely epithelialized after 6-month follow-up [27]. In another case report, a Saudi female patient with ulcerative LP of the soles resistant to many systemic and topical agents responded excellently to topical tacrolimus $0.1 \%$ ointment. Complete healing was reported in a few weeks as well as good maintenance during a follow-up period of more than 2 years [28].

\section{Surgery and cyclosporine A}

Patrone et al. demonstrated a recalcitrant case of a 68-year-old man with a 10-year history of painful, disabling, ulcerative LP on the soles of both feet who temporarily improved due to cyclosporine A. Cyclosporine A treatment was begun and after 10 days the ulcer on his left sole was covered with a Thiersch split-skin graft. The grafting was successful, so cyclosporine A was gradually reduced to smaller maintenance doses and 10 months later it was completely withdrawn. The result was good after eighteen months following grafting and 10 months after total withdrawal of cyclosporine A [29].

\section{Surgery}

There are two reports of recalcitrant and painful, hypertrophic ulcerative LP of the hands and feet in the English literature; in both, patients responded to surgical treatment with excision and split skin grafting. There was no recurrence after 14-year follow-up in one of them. The other one achieved a satisfactory long-term outcome. Accordingly, it has been suggested that surgical treatment should be considered in painful LP of the hands and feet [30]. 


\section{Miscellaneous}

There is a case of cutaneous LP and palmoplantar hyperkeratosis due to the use of imatinib mesylate for chronic myeloid leukaemia in a 57-year-old man. The skin lesions improved after discontinuation of imatinib mesylate but re-administration of the drug at a lower dose provoked a mild recurrence but skin lesions were wellcontrolled by topical corticosteroid treatment [31].

There are many other chemical and herbal drugs such as Aloe Vera, green tea [32, 33], sulfasalazine, metronidazole [18], mycophenolate mofetil [34], griseofulvin, thalidomide and therapeutic modalities such as PUVA and bath PUVA [35], excimer laser [36], UVA1 radiation and extracorporeal phototherapy used in the treatment of LP or generalized LP [18] or other palmoplantar dermatoses but just the above-mentioned drugs have been used in the treatment of palmoplantar LP. As mentioned before palmoplantar $L P$ is a rare variety of $L P$, that is why we could not find any clinical trial and just case reports have been described in this manuscript.

\section{Discussion}

Palmoplantar LP can pose a diagnostic problem to the clinician as it resembles many dermatoses [2, 15-17]. In spite of plentiful investigations carried out on LP, there is no treatment modality that has proved to be utterly satisfactory in treatment of palmoplantar LP [8]. Many drugs have been used in the treatment of LP and generalized LP [18] but just a few case reports and drugs have been described in the treatment of palmoplantar LP. In this review article we have gone over about 24 articles and discuss all treatment modalities proposed and tested for palmoplantar LP in the literature but because palmoplantar LP is a rare entity we could not find any trial on this subject and just case reports have been found. Drugs such as acitretin, topical and systemic corticosteroid, enoxaparin, topical tacrolimus, topical and systemic cyclosporine and surgery have been used in the treatment of palmoplantar LP with promising results but for better management of this conundrum, additional studies and clinical trials are required.

\section{Conclusions}

In spite of numerous investigations carried out on LP, there is no proved satisfactory therapeutic modality in treatment of palmoplantar LP and additional clinical trials are required.

\section{Conflict of interest}

The authors declare no conflict of interest.

\section{References}

1. Omidian M, Ayoobi A, Mapar MA, et al. Efficacy of sulfasalazine in the treatment of generalized lichen planus: randomized double-blinded clinical trial on 52 patients. J Eur Acad Dermatol Venereol 2010; 24: 1051-4.

2. Madke B, Gutte R, Doshi B, Khopkar U. Hyperkeratotic palmoplantar lichen planus in a child. Indian J Dermatol 2013; 58: 405.

3. Freedberg IM (ed.). Fitzpatrick's Dermatology in General Medicine. $6^{\text {th }}$ ed. McGraw-Hill, New York, NY 2003; 465-8.

4. James WD, Elston DM, Berger TG. Andrews' Diseases of the Skin: Clinical Dermatology. $11^{\text {th }}$ ed. Saunders/Elsevier, London 2014; 219-24.

5. Gönül M, Atay S, Cemil B, et al. A case of unilateral linear lichen planus: Related to orthopedic prosthesis or not? Postep Derm Alergol 2015; 32: 310-1.

6. Yasar S, Serdar ZA, Goktay F, et al. The successful treatment of palmoplantar hyperkeratotic lichen planus with enoxaparin. Indian J Dermatol Venereol Leprol 2011; 77: 64-6.

7. Karakatsanis G, Patsatsi A, Kastoridou C, Sotiriadis D. Palmoplantar lichen planus with umbilicated papules: an atypical case with rapid therapeutic response to cyclosporine. J Eur Acad Dermatol Venereol 2007; 21: 1006-7.

8. De Jong EM, Van De Kerkhof PC. Coexistence of palmoplantar lichen planus and lupus erythematosus with response to treatment using acitretin. Br J Dermatol 1996; 134: 538-41.

9. Günther S. Therapeutic effect of vitamin A acid (retinoic acid) in various forms of palmar/plantar hyperkeratoses: experimental studies on 68 patients. Z Hautkr 1975; 50: 607-15.

10. Gündüz K, Inanir I, Türkdogan P, Sacar H. Palmoplantar lichen planus presenting with vesicle-like papule. J Dermatol 2003; 30: 337-40.

11. Madke B, Doshi B, Wankhede P, Nayak C. Palmar lichen planus mimicking tinea nigra. Indian J Dermatol 2013; 58: 407.

12. Gutte R, Khopkar U. Perforating lichen planus. Indian J Dermatol Venereol Leprol 2011; 77: 515-7.

13. Kim MJ, Choi M, Na SY, et al. Two cases of palmoplantar lichen planus with various clinical features. J Dermatol 2010; 37: 985-9.

14. Rotunda AM, Craft N, Haley JC. Hyperkeratotic plaques on the palms and soles. Palmoplantar lichen planus, hyperkeratotic variant. Arch Dermatol 2004; 140: 1275-80.

15. Gutte RM. Unilateral acrosyringeal lichen planus of palm. Indian Dermatol Online J 2013; 4: 350-2.

16. Gutte RM. Acrosyringeal lichen planus of palm. Indian J Dermatol Venereol Leprol 2012; 78: 521.

17. Zeng YP, Sun QN, Liu YH, Fang K. Lichen planus with palmoplantar involvement: rapid therapeutic response to acitretin. Eur J Dermatol 2011; 21: 632-3.

18. Jiménez-Sánchez MD, Ferrándiz L, Moreno-Ramírez D, et al. Erosive palmoplantar lichen planus. Actas Dermosifiliogr 2012; 103: 448-50.

19. Lospinoso DJ, Fernelius C, Edhegard KD, et al. Lupus erythematosus/lichen planus overlap syndrome: successful treatment with acitretin. Lupus 2013; 22: 851-4.

20. De Jong EM, Van De Kerkhof PC. Coexistence of palmoplantar lichen planus and lupus erythematosus with response to treatment using acitretin. Br J Dermatol 1996; 134: 538-41.

21. Hodak E, Yosipovitch G, David M, et al. Low-dose low-molecular-weight heparin (enoxaparin) is beneficial in lichen planus: a preliminary report. J Am Acad Dermatol 1998; 38: 564-8. 
22. Stefanidou MP, Ioannidou DJ, Panayiotides JG, Tosca AD. Low molecular weight heparin; a novel alternative therapeutic approach for lichen planus. Br J Dermatol 1999; 141: 1040-5.

23. Schepis C, Siragusa M, Lentini M. Erosive lichen planus: two uncommon cases. Acta Derm Venereol 2008; 88: 268-70.

24. Sánchez-Pérez J, Rios Buceta L, Fraga J, García-Díez A. Lichen planus with lesions on the palms and/or soles: prevalence and clinicopathological study of 36 patients. Br J Dermatol 2000; 142: 310-3.

25. Cheung-Lee MJ, Rao J. Violaceous papules on the palms and soles. J Cutan Med Surg 2008; 12: 35-7.

26. Paçi M, Silva R. Treatment of plantar erosive lichen planus with topical cyclosporine. J Eur Acad Dermatol Venereol 2001; 15: 79-80.

27. Ojeda T, Rodríguez-Rey E, Camacho FM. Ulcerative lichen planus of the sole treated with tacrolimus, $0.1 \%$. Actas Dermosifiliogr 2011; 102: 383-4.

28. Al-Khenaizan S, Al Mubarak L. Ulcerative lichen planus of the sole: excellent response to topical tacrolimus. Int I Dermatol 2008; 47: 626-8.

29. Patrone P, Stinco G, La Pia E, et al. Surgery and cyclosporine $A$ in the treatment of erosive lichen planus of the feet. Eur J Dermatol 1998; 8: 243-4.

30. Moss AL, Harman RR. Surgical treatment of painful lichen planus of the hand and foot. Br J Plast Surg 1986; 39: 402-7.

31. Kuraishi N, Nagai Y, Hasegawa M, Ishikawa O. Lichenoid drug eruption with palmoplantar hyperkeratosis due to imatinib mesylate: a case report and a review of the literature. Acta Derm Venereol 2010; 90: 73-6.

32. Feily A, Namazi MR. Aloe vera in dermatology: a brief review. G Ital Dermatol Venereol 2009; 144: 85-91.

33. Pazyar N, Yaghoobi R, Rafiee E, et al. Skin wound healing and phytomedicine: a review. Skin Pharmacol Physiol 2014; 27: 303-10.

34. Frieling U, Bonsmann G, Schwarz T, et al. Treatment of severe lichen planus with mycophenolate mofetil. J Am Acad Dermatol 2003; 49: 1063-6.

35. Grundmann-Kollmann M, Behrens S, Peter RU, Kerscher M. Treatment of severe recalcitrant dermatoses of the palms and soles with PUVA-bath versus PUVA-cream therapy. Photodermatol Photoimmunol Photomed 1999; 15: 87-9.

36. Mehraban S, Feily A. $308 \mathrm{~nm}$ excimer laser in dermatology. J Lasers Med Sci 2014; 5: 8-12. 